\title{
Efficiency of Different Anti-Dust Agents in Reducing Dust Emission from Forest Road and Deposition on Leaf Surface
}

\author{
Aidin Parsakhoo, Seyed Ataollah Hosseini, Majid Lotfalian, \\ Jahangir Mohammadi, Meysam Salarijazi
}

\begin{abstract}
Dust is often generated from the dry surfaces of unpaved forest roads as a result of vehicular traffic. Dust particles can negatively affect vegetative growth, water quality and road traffic quality. In this study, some environmental friendly anti-dust agents including sugar cane molasses, polyacrylamide (PAM) and bentonite were used to control dust emission from the road surface under three different concentrations within the 3, 9, 27 and 81 day timeframe. Rear-mounted spray system and dustometer devices were used for implementation of treatments and dust emission recording, respectively. Leaf samples were collected from trees adjacent to road to measure the dust deposited on the leaves by centrifuging dust solution. The results showed that molasses achieved higher efficiencies in term of dust reduction and cost effectiveness than those of PAM and bentonite in Loveh forest, where high levels of fines are present in the road surface materials. $2 \%$ and $4 \%$ PAM were the most efficient dosages in terms of dust control and cost effectiveness in Shastkalateh and Kouhmian forests, respectively. It was detected that in all sites most of the dust emitted from the road surface was deposited on the leaves of Carpinus betulus L. and Alnus subcordata L., while smooth surface of the leaves retained lower amount of dust in Parrotia persica CAM. It is concluded that the amount of fine aggregates in surfacing materials, type and dosage of anti-dust agent play an important role in the effectiveness and longevity of treatment.
\end{abstract}

Keywords: PAM, sugar cane molasses, bentonite, leaf samples, dustometer

\section{Introduction}

An unpaved forest road in the standard state consists of $40-80 \%$ gravel, $20-60 \%$ sand and $8-15 \%$ fine particles such as silt and clay (Gotosa et al. 2015). The major problem of these roads, especially in summer, is the generation of dust due to vehicle traffic. Dust particles with diameter less than $150 \mu \mathrm{m}$, generated in the form of a cloud behind the vehicles, cause disturbance to tourists (Addo and Sanders 1995), reducing the vision distance of drivers, thus reducing road safety. Suspended dust and particles on vehicles can increase fuel cost, travel time and vehicle depreciation (Jones 1999). Other negative effects of dust include damage to human health, plants growth decline due to disturbance in the gas exchange and photosynthesis (Manoochehri et al. 2016), water and aquatic habitats pollution, pavement destruction (Forman and Alexander 1998) and increased cost of road repairing and maintenance (Gulia et al. 2019). The amount of dust generation is dependent on various factors such as traffic intensity, vehicle weight, vehicle speed (Kuhns et al. 2001, Gillies et al. 2005), the density of surfacing layer (Jones 2000), percentage of fine particles (Smaller than $75 \mu \mathrm{m}$ ) insurfacing materials and moisture of materials (Edvardsson 2010). Observations have shown that the dust emission occurs at a threshold speed of about 25-35 km/h (Jones 1984, Monlux and Mitchell 2007, Powers 2007).

Anti-dust agents agglomerate fine particles, adhere surface particles together and increase road surface density (Bergeson and Brocka 1996). When the road is treated with these agents, fine particles resist to being driven by vehicle traffic or by wind in the air (Jacobson 
1992, Sanders et al. 1997). Generally, anti-dust agents cannot act effectively on the roads that contain more than $30 \%$ and less than $5 \%$ of fine particles in their surfacing materials (Bolander and Yamada 1999). In addition, these treatments in sandy soils have a small efficiency due to little plasticity (Kirchner and Gall 1991). Some anti-dust agents such as petroleum products, lignosulfonates and chlorides can reduce dust emission by up to $90 \%$ (Monlux and Mitchell 2007). However, these treatments are not appropriate for dust control in forest roads due to the environmental considerations (Bennett 1994, Bolander and Yamada 1999). In the case of forest roads, it is necessary to use cost-effective and environmentally friendly agents (Bolander and Yamada 1999). Sugar cane molasses is a thick and dark brown juice that is extracted from the sugarcane stem. It acts as a binder of fine particles on road surface and in this way prevents dust emission (Gotosa et al. 2015). The use of acrylic-based polymer mulch is also expanding because of its environmental friendliness and safety. Polyacrylamides are odorless, colorless and non-polluting in surface and underground waters, plant tissues and soil (Manafi et al. 2016, Wang et al. 2019). Bentonites are swelling clay in the presence of moisture, and they have a high level of inflation, good adhesion and moisture absorbing capacity (Murray 2000, Pusch 2015). Bentonite is used to control dust through electrostatic bonding and agglomeration (Bergeson and Brocka 1996). In literature review, Bergeson and Brocka (1996), Omane et al. (2018), Gotosa et al. (2015) and Ding et al. (2019) used bentonite, polymer and molasses for road dust emission control.

One of the reasons for dust generation in some forest roads are the climatic and geological features of the region. Especially in the east of the Hyrcanian zone, the presence of wind sediments in the form of silt, clay and sand particles cause massive dust as a result of rapid destruction of the forest road. This issue has led to a high annual cost for the renewal of materials and restoration of forest roads. However, the anti-dust agents have been shown to contribute to the coherence of road surfacing materials, which can delay materials renewal and maintenance operations (Morgan et al. 2005). Despite the fact that anti-dust treatments have been used for decades, few studies have been carried out in Iran regarding their performance evaluation. Most studies have focused on the effects of chemicals on improvement of road strength (Monlux 2003). Although the relationship between road surface compaction and dust emission has been fully acknowledged, few researchers have specifically reported on the rate of dust reduction due to the application of various anti-dust treatments as well as dust retention capacity of forest tree species. Trees play an increasingly important role in the improvement of the forest atmospheric environment (Liu et al. 2013).

\subsection{Research Objectives}

The objectives of this research were to:

$\Rightarrow$ investigate the effect of the different dosages of sugar cane molasses, polyacrylamide and bentonite treatments on reduction of dust emission from gravel forest roads in Hyrcanian region within the 3, 9, 27 and 81 day timeframe

$\Rightarrow$ determine the appropriate treatment and optimum dosage in each site with considerations of dust reduction efficiency and cost per kilometer

$\Rightarrow$ determine the dust retention capacities of Carpinus betulus L., Alnus subcordata L. and Parrotia persica CAM under different anti-dust agent concentrations.

\section{Material and Methods}

\subsection{Study Area and Sampling Plan}

This study was carried out on three sites distributed in the forests of Golestan province, north of Iran. First, parts of the main forest roads in the Loveh $\left(55^{\circ} 41^{\prime} 00^{\prime \prime}\right.$ to $55^{\circ} 46^{\prime} 00^{\prime \prime} \mathrm{E}$ and $37^{\circ} 19^{\prime} 00^{\prime \prime}$ to $37^{\circ} 20^{\prime} 00^{\prime \prime}$ N), Kouhmian ( $55^{\circ} 10^{\prime} 30^{\prime \prime}$ to $55^{\circ} 14^{\prime} 49^{\prime \prime}$ E and $37^{\circ} 00^{\prime} 00^{\prime \prime}$ to $\left.37^{\circ} 56^{\prime} 15^{\prime \prime} \mathrm{N}\right)$ and Shastkalateh $\left(54^{\circ} 21^{\prime} 26^{\prime \prime}\right.$ to $54^{\circ} 24^{\prime} 57^{\prime \prime}$ E from $36^{\circ} 48^{\prime} 06^{\prime \prime}$ to $36^{\circ} 43^{\prime} 27^{\prime \prime} \mathrm{N}$ ) with serious problems in terms of dust production were selected (Fig. 1). The surfacing type and thickness of roads was recorded by digging trenches at the beginning, middle and end of each segment. Samples with a weight of $15 \mathrm{~kg}$ were collected from each trench and then transferred to the Soil Mechanics Laboratory, where the granulation analysis was carried out according to ASTM-D422 (2007). Road superstructure types in Kouhmian, Shastkalateh and Loveh are river-mine, river and mine aggregates, respectively. Each site road cross section was the same. The width and transverse slope of the selected road segments in all sites were $5.5-6 \mathrm{~m}$ and $3-5 \%$, respectively. The mean traffic in the studied roads was 25 vehicle passes per day. Two axle vehicles with height equal to or less than $2.2 \mathrm{~m}$ used these roads. In each site, a 960-meter of main forest road in the northern direction and on alignment was selected and various treatments of sugar cane molasses, polyacrylamide and bentonite were carried out at a distance of $320 \mathrm{~m}$ with an interval of $20 \mathrm{~m}$ among treatments (Gotosa et al. 2015). The characteristics of 

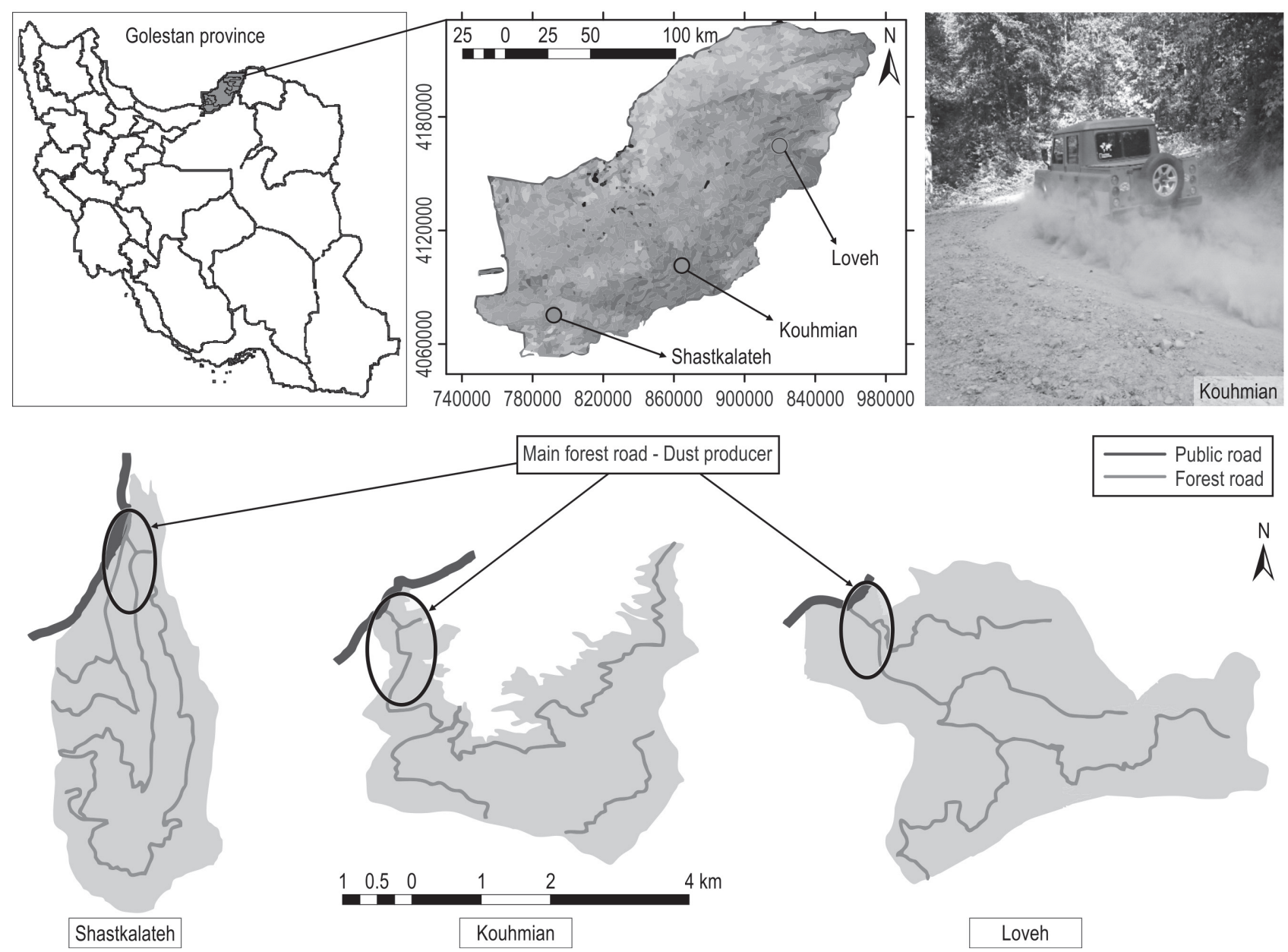

Fig. 1 Position of road segments in study sites for implementation of treatments

the study area and different treated road segments with anti-dust agents are described in Table 1. The study design was a completely randomized block.
Each treatment was repeated three times in the study area as three blocks and three replications in each block (Fig. 2).

Table 1 Characteristics of road segments containing treatments of molasses, bentonite and PAM

\begin{tabular}{|c|c|c|c|c|c|c|c|c|c|c|c|c|c|}
\hline $\begin{array}{l}\text { Study } \\
\text { area }\end{array}$ & Treatment & $\begin{array}{c}\text { Road } \\
\text { slope } \\
\%\end{array}$ & $\begin{array}{c}\text { Elevation at } \\
\text { sea level } \\
m\end{array}$ & $\begin{array}{c}\text { Material } \\
\text { moisture } \\
\%\end{array}$ & \begin{tabular}{|c|} 
Surfacing \\
thickness \\
$\mathrm{cm}$
\end{tabular} & $\begin{array}{c}\text { Pavement fine } \\
\text { aggregates } \\
\%\end{array}$ & $\begin{array}{c}\text { Material } \\
\text { class } \\
\%\end{array}$ & $\begin{array}{c}\text { Annual } \\
\text { temperature } \\
{ }^{\circ} \mathrm{C}\end{array}$ & $\begin{array}{c}\text { Annual } \\
\text { rainfall } \\
\mathrm{mm} / \mathrm{h}\end{array}$ & $\begin{array}{c}\text { Forest } \\
\text { soil }\end{array}$ & $\begin{array}{c}\text { Canopy } \\
\text { cover } \\
\%\end{array}$ & \begin{tabular}{|c|} 
Road \\
age \\
year
\end{tabular} & Climate \\
\hline \multirow{3}{*}{ Loveh } & Molasses & 4 & $300-400$ & 5 & 15 & 11 & $\mathrm{GP}$ & 12.20 & 524 & \multirow{3}{*}{ Brown-ML } & 60 & \multirow{3}{*}{2007} & \multirow{3}{*}{ Moist } \\
\hline & PAM & 5 & $300-400$ & 4 & 16 & 14 & GP & 12.20 & 524 & & 65 & & \\
\hline & Bentonite & 6 & $300-400$ & 5 & 14 & 12 & $\mathrm{GP}$ & 12.20 & 524 & & 60 & & \\
\hline \multirow{3}{*}{ Kouhmian } & Molasses & 5 & $320-420$ & 6 & 15 & 9 & GP & 16.83 & 700 & \multirow{3}{*}{ Brown-ML } & 65 & \multirow{3}{*}{1993} & \multirow{3}{*}{$\begin{array}{l}\text { Moderate } \\
\text { moist to } \\
\text { mid moist }\end{array}$} \\
\hline & PAM & 4 & $320-420$ & 6 & 15 & 6 & GP & 16.83 & 700 & & 60 & & \\
\hline & Bentonite & 5 & $320-420$ & 5 & 16 & 7 & $\mathrm{GP}$ & 16.83 & 700 & & 60 & & \\
\hline \multirow{3}{*}{ Shastkalateh } & Molasses & 4 & 250-350 & 6 & 15 & 5 & GW & 18.00 & 562 & \multirow{3}{*}{ Brown-ML } & 55 & \multirow{3}{*}{1971} & \multirow{3}{*}{$\begin{array}{c}\text { Moderate } \\
\text { moist }\end{array}$} \\
\hline & PAM & 5 & 250-350 & 5 & 16 & 4 & GW & 18.00 & 562 & & 65 & & \\
\hline & Bentonite & 7 & 250-350 & 6 & 16 & 5 & GW & 18.00 & 562 & & 60 & & \\
\hline
\end{tabular}

GW - well-graded gravel; GP - poorly graded gravel; ML - marl soil with low plasticity 


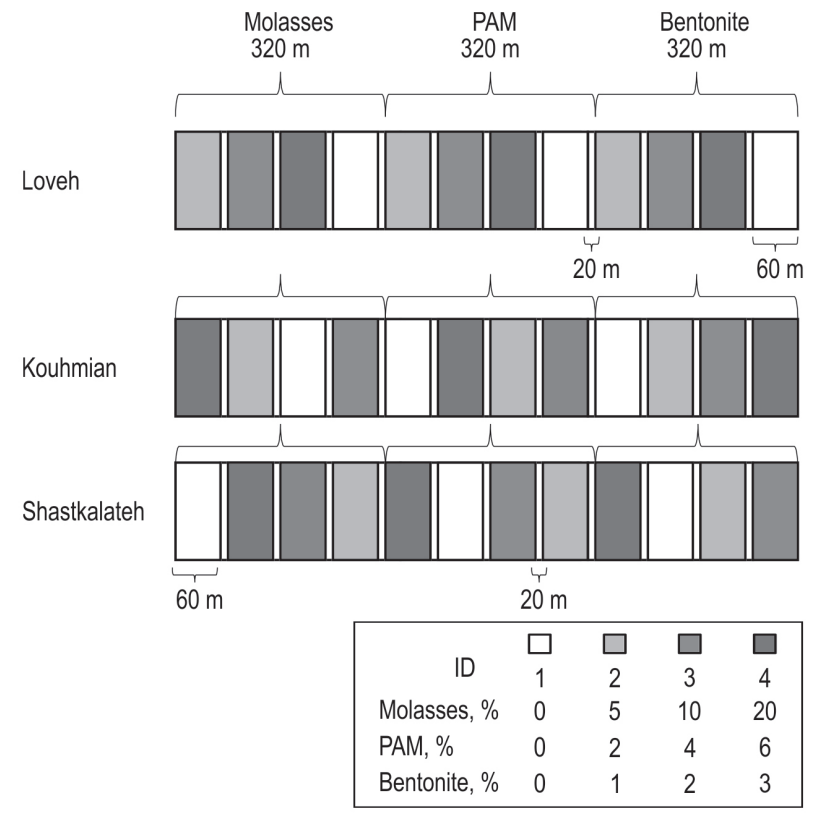

Fig. 2 Sample plots in completely randomized block design

\subsection{Implementation of Treatments}

In this study, anti-dust treatments were prepared in different concentrations (Fig. 2) and then applied using a rear-mounted spray system equipped with a 100 liter capacity tank and a motor-pump (Fig. 3a). The proportion of the volume of anti-dust agents to the amount of water that dissolves were $5 \%, 10 \%$ and $20 \%$ for the sugar cane molasses (Brown and Elton 1994, Gotosa et al. 2015) and 2\%, 4\% and 6\% for polyacrylamide (Sadeghi et al. 2016, Kristian Aase et al. 1998, McLaughlin et al. 2014). The ratio of the weight of bentonite to the weight of the materials added to it was $1 \%, 2 \%$ and 3\% (Edwards et al. 2016). The treatment rates were 2-2.5 liter per square meter (Addo et al. 2004). Each concentration was carried out on a road segment with a length of 60 meters at 20 meter intervals. Field observations showed that a space of 20 meters was enough to prevent intermingling of treatments. Traffic was restricted for 24 hours to allow the solution to penetrate into the road. There was no harvesting or skidding in the field during the work. Chemical composition of anti-dust agents used in this study is shown in Table 2.

\subsection{Measuring of Dust Emitted from Road Trails}

Dustometer was used to determine the dust concentration in the air (Fig. 3b). This device was attached behind a vehicle to collect dust samples within the 3, 9, 27 and 81 day timeframe (from 28 May to 17 August 2019). This timeframe was determined according to
Table 2 Chemical composition of anti-dust agents used in current study

\begin{tabular}{|c|c|c|c|c|}
\hline \multicolumn{2}{|c|}{ Sugar cane molasses } & \multirow{2}{*}{ Chemicals of PAM } & \multicolumn{2}{|c|}{ Chemicals of bentonite } \\
\hline Chemicals & $\%$ & & Chemicals & $\%$ \\
\hline $\begin{array}{l}\text { Non-fermentable } \\
\text { sugar }\end{array}$ & 4.50 & \multirow{13}{*}[\begin{array}{cc}{\mathrm{CH}_{2}}&{-\mathrm{HC}}\\
{}&{|}\\
{}&{|_{\mathrm{C}=0}}\\
{}&{}\end{array}\mathrm{NH}_{2}]{$_{\mathrm{n}}$} & $\mathrm{MgO}$ & 4.22 \\
\hline $\begin{array}{l}\text { Fermentable } \\
\text { sugar }\end{array}$ & 51.50 & & $\mathrm{Al}_{2} \mathrm{O}_{3}$ & 11.75 \\
\hline $\begin{array}{l}\text { Reducing } \\
\text { sugar }\end{array}$ & 24.90 & & $\mathrm{SiO}_{2}$ & 63.13 \\
\hline Nitrogen & 0.42 & & $\mathrm{P}_{2} \mathrm{O}_{5}$ & 0.07 \\
\hline Protein & 3.00 & & $\mathrm{SO}_{3}$ & 0.15 \\
\hline $\mathrm{CaO}$ & 1.58 & & $\mathrm{Cl}$ & 1.41 \\
\hline $\mathrm{SO}_{4}$ & 0.35 & & $\mathrm{MnO}$ & 0.09 \\
\hline $\mathrm{P}_{2} \mathrm{O}_{5}$ & 0.30 & & $\mathrm{Na}$ & 0.91 \\
\hline $\mathrm{MgO}$ & 0.36 & & $\mathrm{Na}_{2} \mathrm{O}$ & 1.99 \\
\hline $\mathrm{K}_{2} \mathrm{O}$ & 3.00 & & $\mathrm{TiO}_{2}$ & 0.37 \\
\hline Ash & 10.09 & & $\mathrm{~K}_{2} \mathrm{O}$ & 1.21 \\
\hline- & - & & $\mathrm{CaO}$ & 2.13 \\
\hline- & - & & $\mathrm{Fe}_{2} \mathrm{O}_{3}$ & 3.35 \\
\hline
\end{tabular}

dry season extracted from Ombrothermic diagram of the study sites. The dustometer used in the current study is a mobile sampler that measures a quantity of how much dust is emitted from a road trail to the air $\left(\mathrm{g} / \mathrm{m}^{3}\right)$, when a vehicle moves at a speed of $40 \mathrm{~km} / \mathrm{h}$ (Sanders and Addo 2000, Addo et al. 2004). The dustometer includes a fiberglass box to hold a $20 \times 20 \mathrm{~cm}$ glass wool fitted to the rear bumper, an electric engine, a high volume collector pump, a flexible plastic tube, one meter metal boom,head and filter box. The filter box has an input of $25 \times 25 \mathrm{~cm}$ and it is covered by a filter with $450 \mu \mathrm{m}$ apertures. This filter score $(450 \mu \mathrm{m})$ prevents the entry of non-volatile particles into the filter box. In dust sampling, first, the empty filter was weighted and then the collector boom was drawn to the rear of a Land Rover $(1900 \mathrm{~kg})$ at the elevation of $40 \mathrm{~cm}$ from the road surface. The collector was turned on when Land Rover began to move (Jones 1984) and after the 60 meters it was turned off and the filter was removed for weighing. The difference between the final and initial weight of the filter wass the weight of the dust in each sampling. The determination of dust concentration was done according to protocols developed at the Colorado State University (Addo and Sanders 1995). This procedure was repeated 5 times for each treatment. Thus a total of 720 samples were taken. 

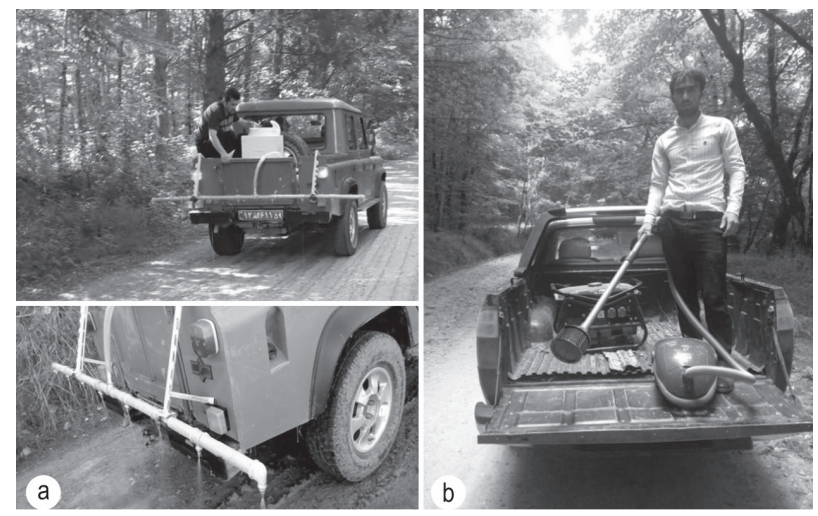

Fig. 3 Rear-mounted (a) spray system and (b) dustometer used in current study

\subsection{Measuring Dust-Retaining Capability of Adjacent Trees}

Carpinus betulus L., Parrotia persica CAM and Alnus subcordata L. were the frequent species at the edge of the studied forest roads. 10 trees from each species with independent crown were randomly selected for leaf sampling. 150 leaf samples were randomly collected from different heights of crown in road direction. Sampling was carried out before the implementation of anti-dust treatment on 28 May and after the 81 day timeframe on 17 August 2019. The samples of leaves were transferred to the lab packed in paper bags. The leaves were completely washed in distilled water. Approximately $50 \mathrm{cc}$ dust solutions were centrifuged for 5 minutes at a speed of $5000 \mathrm{rpm}$ to sepa-

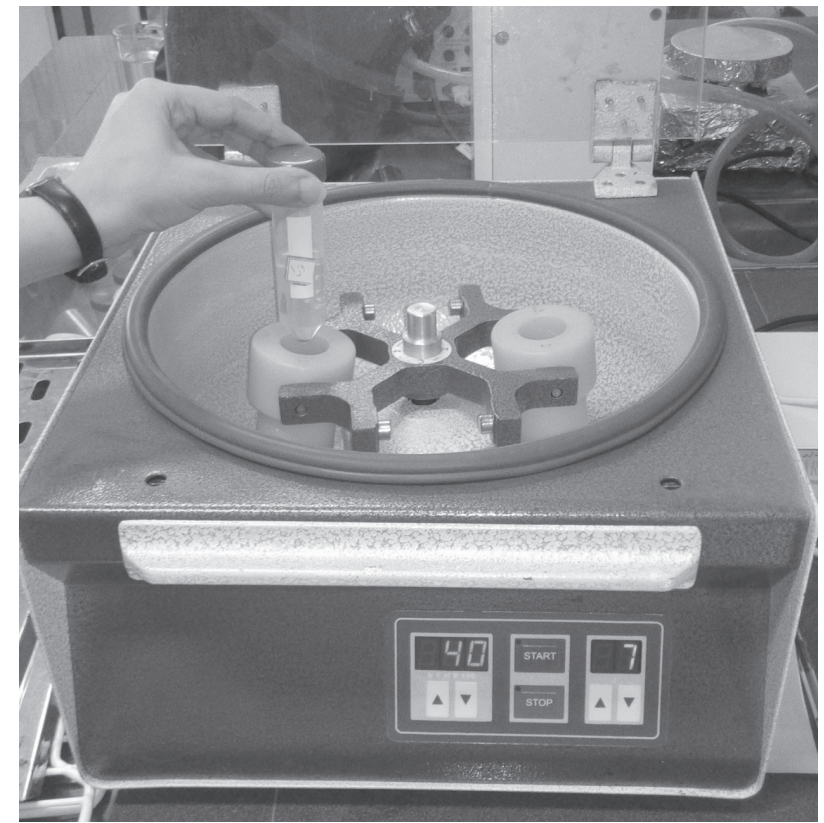

Fig. 4 Centrifuging dust solution in laboratory

rate the dust from distilled water (Fig. 4). The dust particles of the solution were dried for 2 hours at $100^{\circ} \mathrm{C}$ and weighed with a digital scale at a precision of $0.001 \mathrm{~g}$. The mean leaf area for each species was measured through scanning leaves and processing in Image J software (Fig. 5). Image J is a Java-based image processing program developed at the National Institutes of Health and the Laboratory for Optical and Computational Instrumentation (LOCI, University of Wisconsin).

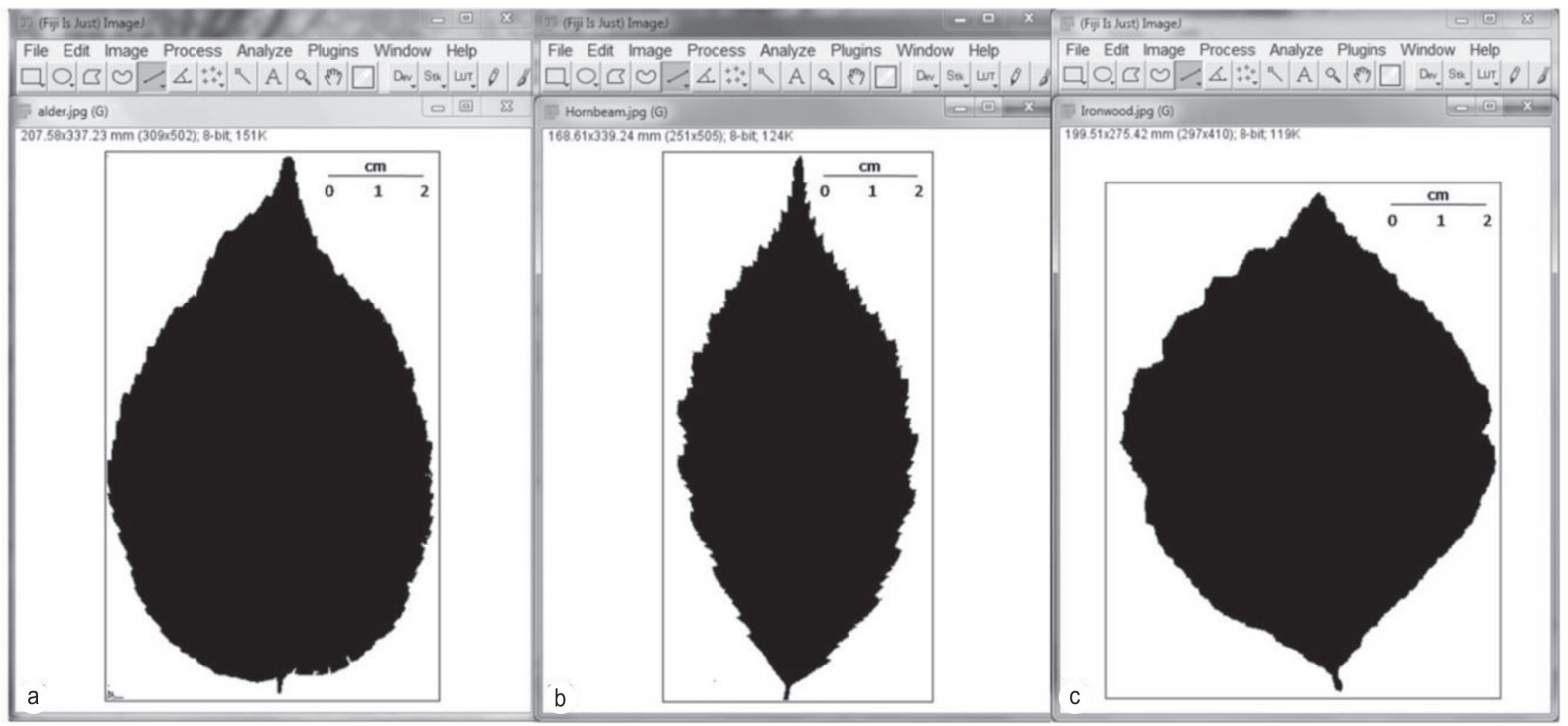

Fig. 5 Measuring leaf area for (a) Alnus subcordata L., (b) Carpinus betulus L. and (c) Parrotia persica CAM in Image J software 
The amount of deposited dust was calculated in the leaf area unit by dividing dust mass to mean leaf area (Manouchehri et al. 2016).

\subsection{Cost and Statistical Analysis}

Total cost of purchasing, transportation and performing of molasses, PAM and bentonite treatments for the dust emission control in a forest road with travel way of 3.5 meters was calculated based on 2019 fee-table. The normality of the data was tested using the Kolmogorov-Smirnov and then subjected to analysis of variance (ANOVA) in SAS software. The mean comparison was performed based on the Fisher's least significant different (LSD) test. The effect and significance of each measured variable and their impact on the road dust emission were examined using Pearson's correlation.

\section{Results and Discussion}

\subsection{Comparison of Anti-Dust Dosages for Dust Reduction on Forest Roads}

Table 3 shows the relationship of the emitted dust from the road segments in each study site versus the attributes on those segments. Results indicated that emitted dust tend to decrease with the increase of anti-dust agent concentrations. Moreover, the emitted dust started to increase with time, with minimum efficiency at the end of the $81^{\text {st }}$ day. Bolander and Yamada (1999) reported that the longevity of the effectiveness of bentonite, PAM and molasses is at least one year. It seems that three rainfall occurrences in our study on 1 June (rainfall: $21.6 \mathrm{~mm}$, temperature: $24^{\circ} \mathrm{C}$, relative humidity: $68 \%$ ), 14 June (rainfall: $4.9 \mathrm{~mm}$, temperature: $26^{\circ} \mathrm{C}$, relative humidity: $72 \%$ ) and 11 July 2019 (rainfall: $4.1 \mathrm{~mm}$, temperature: $26^{\circ} \mathrm{C}$, relative humidity: $75 \%$ ) washed a part of anti-dust agents from the road surface and this may be the reason of increased dust emission at the end of the $81^{\text {st }}$ day. The rainfall occurrences were the same for all segments in each site. Therefore, it had no influence on precision and confidence of results. In Loveh, different concentrations of bentonite could not control the emitted dust from the treated road segments within the 81 day timeframe. Indeed, the longevity of this anti-dust agent is less than 81 days. Bentonite is most effective in conditions where low levels of fines are present in the surface materials (Bennett 1994, Lohnes and Coree 2002), while the surfacing material of forest roads in Loveh is poorly graded gravel (GP) with a high level of fines, so added clay particles could not provide fines needed to bind surface aggregates. In Kouhmian, a minimum amount of emitted dust was detected in dosage of 3\% bentonite. In this dosage, emitted dust decreased from $10.4 \mathrm{~g} / \mathrm{m}^{3}$ to $6.1 \mathrm{~g} / \mathrm{m}^{3}$ on $81^{\text {st }}$ day. Only a few studies have measured dust abatement from bentonite. Bergeson and Brocka (1996) used bentonite (sodium montmorillonite) as a dust palliative on limestone surfaced secondary roads in Texas. Applications tested ranged from $0.5 \%$ to $9 \%$ by weight of aggregate. Dust generation was reduced by about $45 \%$ on sites where $3 \%$ bentonite was employed and $70 \%$ on sites with $9 \%$ bentonite.

In Loveh and Kouhmian, the longevity of PAM treated road segments with concentration of $4 \%$ and $6 \%$ was more than 81 days. The optimum dosage of PAM in Loveh and Kouhmian were $6 \%$ and $4 \%$, respectively. This conforms to the research by Omane et al. (2018). They found an appropriate dosage of $5 \%$ for the chloride-free solution, polymer and molasses. In Shastkalateh, a dosage of $2 \%$ was determined as an optimum amount of PAM for dust reduction because beyond this dosage, adding more concentrations had no impact on the dust emission. A dosage of $20 \%$ was observed as an optimum amount of molasses for the dust reduction in Loveh and Kouhmian, because a lower dosage had no impact on the dust reduction within the 81 day timeframe. In this dosage, emitted dust decreased from $12.3 \mathrm{~g} / \mathrm{m}^{3}$ to $5.0 \mathrm{~g} / \mathrm{m}^{3}$ and from $10.4 \mathrm{~g} / \mathrm{m}^{3}$ to $5.0 \mathrm{~g} / \mathrm{m}^{3}$ in Loveh and Kouhmian, respectively. In Shastkalateh forest, at the initial stage of application, molasses was highly efficient, but as time progressed the dust emission increased. This result is in agreement with the findings of Shirsavkar and Koranne (2010) and Gotosa et al. (2015). Gotosa et al. (2015) examined the potential of molasses (sugar syrup) and water in reducing the dust emission from gravel roads and compared them with a control treatment in Zimbabwe. Each treatment was carried out at

Table 3 Correlations between dust emission rates and site attributes

\begin{tabular}{l|c|c|c|}
\hline \multicolumn{1}{|c|}{ Attributes } & Loveh & Kouhmian & Shastkalateh \\
\hline Road slope & $0.028^{\text {ns }}$ & $0.259^{\text {ns }}$ & $-0.029^{\text {ns }}$ \\
\hline Surfacing thickness & $-0.122^{\text {ns }}$ & $0.127^{\text {ns }}$ & $-0.143^{\text {ns }}$ \\
\hline Pavement fine aggregates & $-0.108^{\text {ns }}$ & $0.197^{\text {ns }}$ & $0.176^{\text {ns }}$ \\
\hline Pavement moisture & $0.125^{\text {ns }}$ & $-0.127^{\text {ns }}$ & $0.176^{\text {ns }}$ \\
\hline Canopy cover & $-0.125^{\text {ns }}$ & $0.132^{\text {ns }}$ & $-0.184^{\text {ns }}$ \\
\hline Anti-dust concentration & $-0.817^{* *}$ & $-0.748^{* *}$ & $-0.744^{* *}$ \\
\hline Time & $0.355^{*}$ & $0.364^{*}$ & $0.355^{*}$ \\
\hline
\end{tabular}
*., ** significant at probability level of 5 and $1 \%$, respectively
ns: not significant


a rate of 4 liter per square meter. The results showed that the dust reduction capacity of molasses and water were $83-77 \%$ and $18-39 \%$, respectively. Molasses contains sugars which are hygroscopic and attract moisture from the air (Manyuchi et al. 2018). The hygroscopic nature of the molasses was therefore the reason of reduced dust emission (Gotosa et al. 2015). Gotosa et al. (2015) detected that molasses was a better suppressant than water over the six month study period (Table 4).

\subsection{Comparison of Different Anti-Dust Agents in the Study Sites}

In Loveh and Kouhmian, PAM and molasses treated road segments had lower emitted dust than bentonite treated road segments. In Loveh, dust reduction efficiencies were $42.34 \%, 52.50 \%$ and $56.06 \%$ and these efficiencies in Kouhmian were $42.99 \%, 52.39 \%$ and $63.14 \%$ for the bentonite, molasses and PAM, respectively $(P<0.05$, Fig. 6a and Fig. 6b). In Shastkalateh, older PAM treated road segments indicate significantly lower emitted dust as compared to molasses and bentonite treated road segments $(P<0.05$, Fig. $6 \mathrm{c})$. For PAM treated road segments in Shastkalateh, dust emission rates ranged from $1.3-1.8 \mathrm{~g} / \mathrm{m}^{3}$ on the $3^{\text {th }}$ day to $2.9-4.1 \mathrm{~g} / \mathrm{m}^{3}$ on the $81^{\text {st }}$ day. In this study site, reduction efficiencies of $56.09 \%, 59.35 \%$ and $70.62 \%$ were achieved for the bentonite, molasses and PAM, respectively. This result is supported by the studies of Omane et al. (2018) and Watson et al. (2000). They reported that the adhesiveness between the molecular structures of the PAM solution is higher, and that a smaller surface tension leads to a decrease of evaporation rate. Other researchers, such as Goma and Mwale (2016) and Thompson and Visser (2007), have reported similar findings. They found that the PAM solution is more

Table 4 Interaction of anti-dust agent concentrations and longevity of dust emitted $\left(\mathrm{g} / \mathrm{m}^{3}\right)$ from treated road segments

\begin{tabular}{|c|c|c|c|c|c|c|c|c|c|c|c|c|c|c|}
\hline \multirow{2}{*}{$\begin{array}{c}\text { Anti-dust } \\
\text { agent }\end{array}$} & \multirow{2}{*}{$\begin{array}{c}\text { Conc. } \\
\%\end{array}$} & & \multicolumn{4}{|c|}{ Longevity in Loveh, day } & \multicolumn{4}{|c|}{ Longevity in Kouhmian, day } & \multicolumn{4}{|c|}{ Longevity in Shastkalateh, day } \\
\hline & & & 3 & 9 & 27 & 81 & 3 & 9 & 27 & 81 & 3 & 9 & 27 & 81 \\
\hline \multirow{8}{*}{ Bentonite } & \multirow{2}{*}{0} & Mean & $12.5^{\mathrm{Aa}}$ & $11.9^{\mathrm{Aa}}$ & $11.4^{\mathrm{Aa}}$ & $12.3^{\mathrm{Aa}}$ & $10.1^{\mathrm{Aa}}$ & $9.7^{\mathrm{Aa}}$ & $9.5^{\mathrm{Aa}}$ & $10.4^{\mathrm{Aa}}$ & $8.7^{\mathrm{Aa}}$ & $9.1^{\text {Aa }}$ & $7.9^{\mathrm{Aa}}$ & $8.0^{\mathrm{Aa}}$ \\
\hline & & SD & 0.79 & 0.79 & 0.76 & 0.74 & 0.82 & 0.86 & 0.79 & 0.76 & 0.21 & 0.50 & 0.43 & 0.38 \\
\hline & \multirow{2}{*}{1} & Mean & $5.3^{\mathrm{Bb}}$ & $6.2^{\mathrm{Bb}}$ & $10.5^{\mathrm{Aa}}$ & $11.7^{\mathrm{Aa}}$ & $4.7^{\mathrm{Bb}}$ & $5.4^{\mathrm{Bb}}$ & $8.6^{\mathrm{Aa}}$ & $9.7^{\mathrm{Aa}}$ & $3.3^{\mathrm{Bb}}$ & $3.5^{\mathrm{Bb}}$ & $4.6^{\mathrm{Bb}}$ & $7.0^{\mathrm{Aa}}$ \\
\hline & & SD & 0.41 & 0.14 & 0.91 & 0.42 & 0.47 & 0.32 & 0.30 & 0.35 & 0.37 & 0.45 & 0.42 & 0.29 \\
\hline & \multirow{2}{*}{2} & Mean & $3.8^{\mathrm{Bb}}$ & $5.4^{\mathrm{Bb}}$ & $5.9^{B b}$ & $11.0^{\mathrm{Aa}}$ & $3.1^{\mathrm{Bb}}$ & $4.5^{\mathrm{Bb}}$ & $5.4^{\mathrm{Bb}}$ & $9.2^{\mathrm{Aa}}$ & $2.8^{\mathrm{Bb}}$ & $3.0^{\mathrm{Bb}}$ & $3.7^{\mathrm{Bb}}$ & $5.3^{\mathrm{Ba}}$ \\
\hline & & SD & 0.57 & 0.32 & 0.64 & 0.96 & 0.07 & 0.41 & 0.40 & 0.44 & 0.23 & 0.28 & 0.56 & 0.35 \\
\hline & \multirow{2}{*}{3} & Mean & $3.4^{\mathrm{Bb}}$ & $4.1^{\mathrm{Bb}}$ & $5.0^{\mathrm{Bb}}$ & $10.9^{\mathrm{Aa}}$ & $3.0^{\mathrm{Bb}}$ & $3.9^{\mathrm{Bb}}$ & $4.3^{\mathrm{Bb}}$ & $6.1^{\mathrm{Ba}}$ & $2.1^{\mathrm{Bb}}$ & $2.3^{\mathrm{Bb}}$ & $2.6^{\mathrm{Bb}}$ & $4.2^{\mathrm{Ba}}$ \\
\hline & & SD & 0.16 & 0.22 & 0.38 & 0.80 & 0.35 & 0.16 & 0.32 & 0.37 & 0.14 & 0.22 & 0.29 & 0.14 \\
\hline \multirow{8}{*}{ PAM } & \multirow{2}{*}{0} & Mean & $12.5^{\text {Aa }}$ & $11.9^{\text {Aa }}$ & $11.4^{\mathrm{Aa}}$ & $12.3^{\mathrm{Aa}}$ & $10.1^{\mathrm{Aa}}$ & $9.7^{\text {Aa }}$ & $9.5^{\mathrm{Aa}}$ & $10.4^{\mathrm{Aa}}$ & $8.7^{\text {Aa }}$ & $9.1^{\mathrm{Aa}}$ & $7.9^{\text {Aa }}$ & $8.0^{\mathrm{Aa}}$ \\
\hline & & SD & 0.79 & 0.79 & 0.76 & 0.74 & 0.82 & 0.86 & 0.79 & 0.76 & 0.21 & 0.50 & 0.43 & 0.38 \\
\hline & \multirow{2}{*}{2} & Mean & $4.7^{\mathrm{Bb}}$ & $5.1^{\mathrm{Bb}}$ & $6.1^{\mathrm{Bb}}$ & $11.0^{\mathrm{Aa}}$ & $2.9^{\mathrm{Bb}}$ & $3.3^{\mathrm{Bb}}$ & $3.9^{\mathrm{Bb}}$ & $9.0^{\mathrm{Aa}}$ & $1.8^{\mathrm{Ba}}$ & $2.4^{\mathrm{Ba}}$ & $3.0^{\mathrm{Ba}}$ & $4.1^{\mathrm{Ba}}$ \\
\hline & & SD & 0.54 & 0.22 & 0.16 & 0.72 & 0.07 & 0.22 & 0.36 & 0.25 & 0.29 & 0.22 & 0.37 & 0.60 \\
\hline & \multirow{2}{*}{4} & Mean & $3.5^{\mathrm{Bb}}$ & $4.2^{\mathrm{Bb}}$ & $5.5^{\mathrm{Bb}}$ & $7.1^{\mathrm{Ba}}$ & $2.4^{\mathrm{Ba}}$ & $3.2^{\mathrm{Ba}}$ & $3.4^{\mathrm{Ba}}$ & $4.0^{\mathrm{Ba}}$ & $1.5^{\mathrm{Ba}}$ & $2.4^{\mathrm{Ba}}$ & $2.6^{\mathrm{Ba}}$ & $3.5^{\mathrm{Ba}}$ \\
\hline & & SD & 0.29 & 0.51 & 0.45 & 0.36 & 0.41 & 0.19 & 0.42 & 0.19 & 0.07 & 0.19 & 0.24 & 0.37 \\
\hline & \multirow{2}{*}{6} & Mean & $3.0^{\mathrm{Ba}}$ & $3.5^{\mathrm{Ba}}$ & $4.1^{\mathrm{Ba}}$ & $5.6^{\mathrm{Ba}}$ & $2.2^{\mathrm{Ba}}$ & $2.8^{\mathrm{Ba}}$ & $3.3^{\mathrm{Ba}}$ & $3.5^{\mathrm{Ba}}$ & $1.5^{\mathrm{Ba}}$ & $2.0^{\mathrm{Ba}}$ & $2.3^{\mathrm{Ba}}$ & $2.9^{\text {Ba }}$ \\
\hline & & SD & 0.49 & 0.45 & 0.36 & 0.35 & 0.32 & 0.38 & 0.12 & 0.50 & 0.07 & 0.07 & 0.28 & 0.14 \\
\hline \multirow{8}{*}{ Molasses } & \multirow{2}{*}{0} & Mean & $12.5^{\mathrm{Aa}}$ & $11.9^{\mathrm{Aa}}$ & $11.4^{\mathrm{Aa}}$ & $12.3^{\mathrm{Aa}}$ & $10.1^{\mathrm{Aa}}$ & $9.7^{\mathrm{Aa}}$ & $9.5^{\text {Aa }}$ & $10.4^{\mathrm{Aa}}$ & $8.7^{\mathrm{Aa}}$ & $9.1^{\mathrm{Aa}}$ & $7.9^{\mathrm{Aa}}$ & $8.0^{\mathrm{Aa}}$ \\
\hline & & SD & 0.79 & 0.79 & 0.76 & 0.74 & 0.82 & 0.86 & 0.79 & 0.76 & 0.21 & 0.50 & 0.43 & 0.38 \\
\hline & \multirow{2}{*}{5} & Mean & $6.0^{\mathrm{Bb}}$ & $6.3^{\mathrm{Bb}}$ & $8.0^{\mathrm{Bb}}$ & $11.1^{\mathrm{Aa}}$ & $5.0^{\mathrm{Bb}}$ & $5.1^{\mathrm{Bb}}$ & $5.8^{8 b}$ & $9.1^{\mathrm{Aa}}$ & $3.1^{\mathrm{Bb}}$ & $4.4^{\mathrm{Bb}}$ & $5.2^{\mathrm{Bb}}$ & $7.2^{\mathrm{Aa}}$ \\
\hline & & SD & 0.61 & 0.25 & 1.0 & 0.53 & 0.07 & 0.07 & 0.72 & 0.26 & 0.57 & 0.56 & 0.24 & 0.81 \\
\hline & \multirow{2}{*}{10} & Mean & $3.9^{\mathrm{Cb}}$ & $5.0^{\mathrm{Bb}}$ & $5.1^{\mathrm{Cb}}$ & $7.0^{\mathrm{Ba}}$ & $3.1^{\mathrm{Cb}}$ & $3.4^{\mathrm{Bb}}$ & $4.1^{\mathrm{Bb}}$ & $6.4^{\mathrm{Ba}}$ & $1.5^{\mathrm{Bb}}$ & $2.0^{\mathrm{Cb}}$ & $3.6^{\mathrm{Bb}}$ & $5.4^{\mathrm{Ba}}$ \\
\hline & & SD & 0.14 & 0.19 & 0.12 & 0.71 & 0.19 & 0.42 & 0.14 & 0.42 & 0.22 & 0.35 & 0.46 & 0.35 \\
\hline & \multirow{2}{*}{20} & Mean & $3.1^{\mathrm{Ca}}$ & $4.0^{\mathrm{Ba}}$ & $4.1^{\mathrm{Ca}}$ & $5.0^{\mathrm{Ca}}$ & $3.0^{\mathrm{Ca}}$ & $3.1^{\mathrm{Ba}}$ & $3.6^{\mathrm{Ba}}$ & $5.0^{\mathrm{Ba}}$ & $1.1^{\mathrm{Bb}}$ & $1.6^{\mathrm{Cb}}$ & $2.1^{\mathrm{Bb}}$ & $3.9^{\mathrm{Ba}}$ \\
\hline & & SD & 0.14 & 0.67 & 0.17 & 0.37 & 0.21 & 0.22 & 0.29 & 0.12 & 0.16 & 0.28 & 0.12 & 0.41 \\
\hline
\end{tabular}



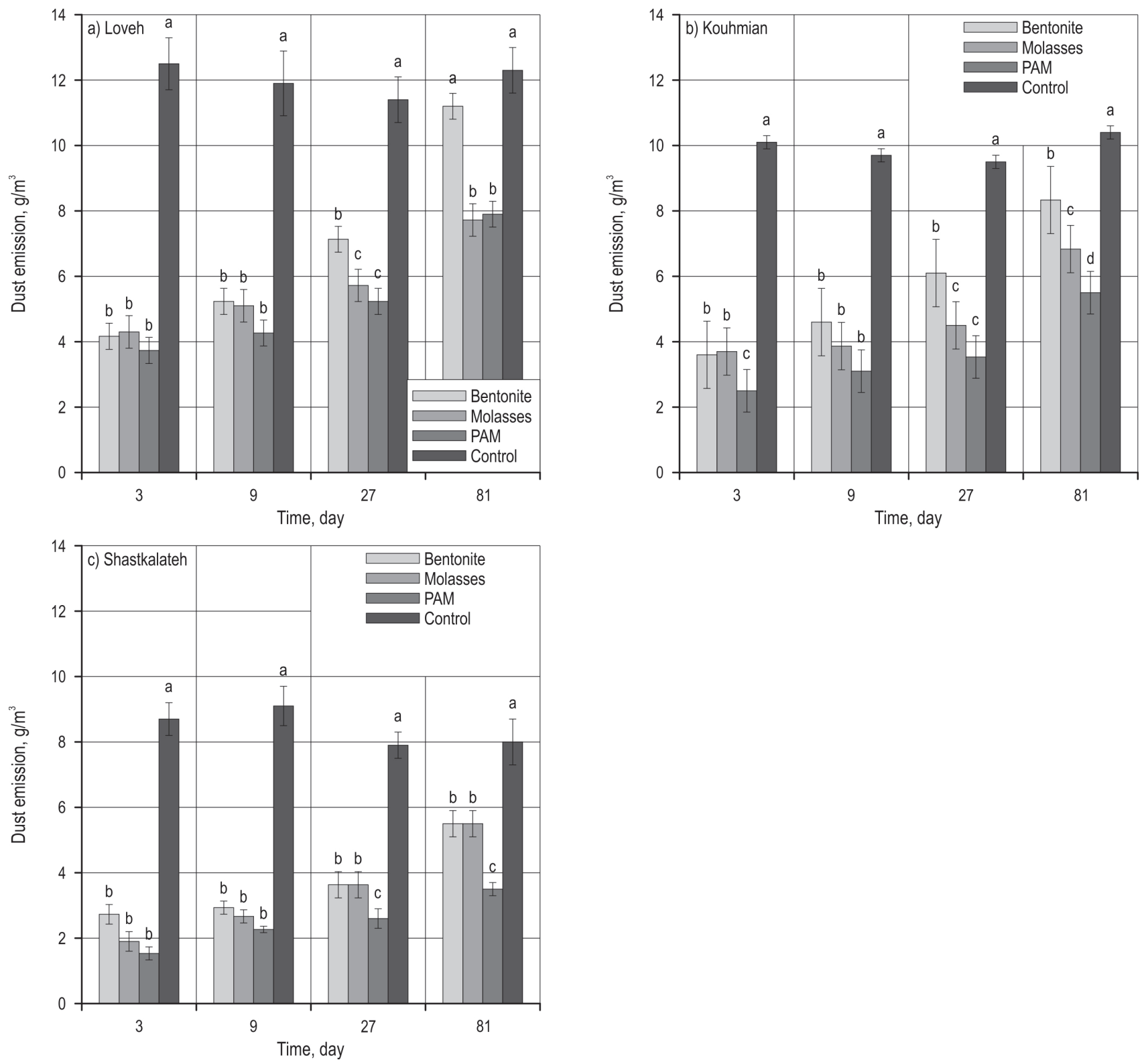

Fig. 6 Comparison of different anti-dust agents in controlling dust emission from treated road segments

efficient than water, the salt solution and the chloridefree solution. PAMs are manufactured in a broad range of molecular weights, charge types and charge densities. Breakdown of PAM requires several weeks and occurs as a result of mechanical disturbances (Ding et al. 2019). As expected, older treated roads exhibit higher dust emission than newer treated roads, and the total amount of dust emissions in Loveh forest roads is larger than that of Kouhmian and Shastkalateh (Fig. 7). Surfacing materials in Loveh forest roads are typically dirty (GP), and poor condition of these materials may contribute to the increased dust emission.
The mean amount of fine particles in surfacing materials of Loveh forest roads was 12.3\%. Gulia et al. (2019) reported that the emission of road dust significantly varies based on the amount of silt deposited on the road, number and type of vehicle movement.

\subsection{Effect of Anti-Dust Treatments on Dust Deposited on Leaves}

The amount of deposited dust per unit leaf area of Parrotia persica CAM., Alnus subcordata L. and Carpinus betulus L. decreased with increasing the concentrations, as there was significantly more deposited dust 


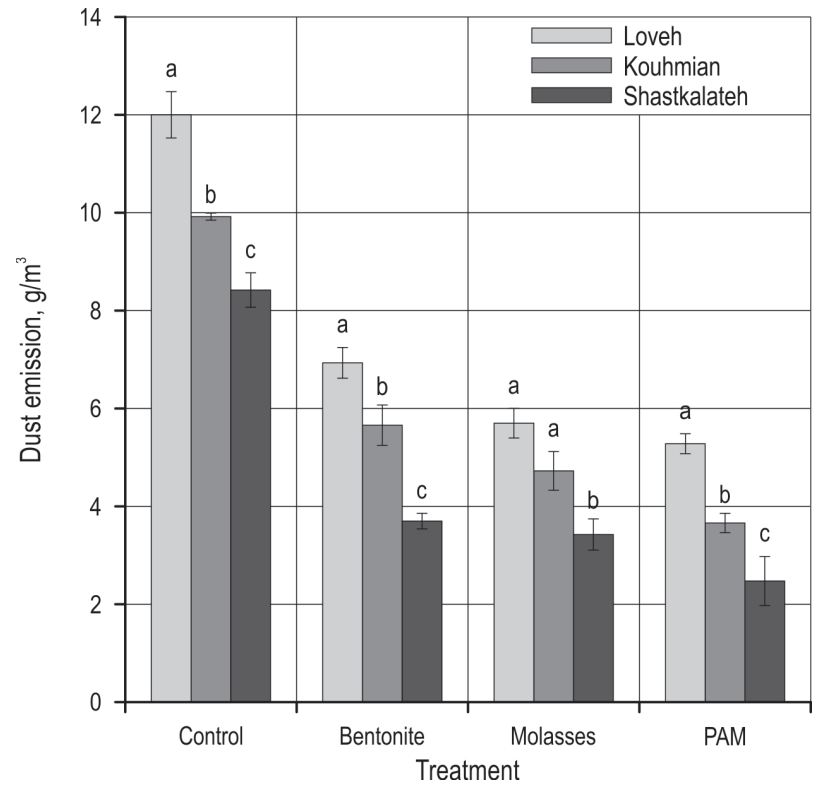

Fig. 7 Comparison of dust emission from treated road segments in different sites per unit leaf area in control treatments of Loveh, Kouhmian and Shastkalateh forests than in road segments treated with molasses, PAM and bentonite $(\mathrm{P}<0.05$, Table 5). The results indicated that in control treatments in Loveh, the amount of deposited dust on Parrotia persica CAM., Alnus subcordata L. and Carpinus betulus L. was $0.043,0.062$ and $0.061 \mathrm{mg} / \mathrm{cm}^{2}$, respectively. In molasses treated road segments, the amount of deposited dust on Parrotia persica CAM $\left(0.027 \mathrm{mg} / \mathrm{cm}^{2}\right)$ was significantly different from those of Alnus subcordata L. $\left(0.044 \mathrm{mg} / \mathrm{cm}^{2}\right)$ and Carpinus betulus L. $\left(0.042 \mathrm{mg} / \mathrm{cm}^{2}\right)$. In PAM treated road segments, the amount of deposited dust per unit leaf area of Parrotia persica CAM $\left(0.022 \mathrm{mg} / \mathrm{cm}^{2}\right)$ was significantly less than that of Alnus subcordata L. $\left(0.036 \mathrm{mg} / \mathrm{cm}^{2}\right)$ and Carpinus betulus L. $\left(0.034 \mathrm{mg} / \mathrm{cm}^{2}\right)$ due to the smooth surface and shallow grooves (Manoochehri et al. 2016). In bentonite treated road segments, the amount of deposited dust on Parrotia persica CAM $\left(0.028 \mathrm{mg} / \mathrm{cm}^{2}\right)$ was significantly lower than that of Alnus subcordata L. $\left(0.043 \mathrm{mg} / \mathrm{cm}^{2}\right)$ and Carpinus betulus L. $\left(0.041 \mathrm{mg} / \mathrm{cm}^{2}\right)$. In other two sites,

Table 5 Deposited dust on leaves $\left(\mathrm{mg} / \mathrm{cm}^{2}\right)$ of adjacent trees in different sites

\begin{tabular}{|c|c|c|c|c|c|c|c|c|c|c|c|}
\hline \multirow{2}{*}{$\begin{array}{l}\text { Anti-dust } \\
\text { agent }\end{array}$} & \multirow{2}{*}{$\begin{array}{c}\text { Conc. } \\
\%\end{array}$} & & \multicolumn{3}{|c|}{ Tree species in Loveh } & \multicolumn{3}{|c|}{ Tree species in Kouhmian } & \multicolumn{3}{|c|}{ Tree species in Shastkalateh } \\
\hline & & & $\begin{array}{l}\text { Carpinus } \\
\text { betulus L. }\end{array}$ & $\begin{array}{c}\text { Alnus } \\
\text { subcordata L. }\end{array}$ & $\begin{array}{c}\text { Parrotia } \\
\text { persica CAM }\end{array}$ & $\begin{array}{l}\text { Carpinus } \\
\text { betulus L. }\end{array}$ & $\begin{array}{c}\text { Alnus } \\
\text { subcordata L. }\end{array}$ & $\begin{array}{c}\text { Parrotia } \\
\text { persica CAM }\end{array}$ & $\begin{array}{l}\text { Carpinus } \\
\text { betulus L. }\end{array}$ & $\begin{array}{c}\text { Alnus } \\
\text { subcordata L. }\end{array}$ & $\begin{array}{c}\text { Parrotia } \\
\text { persica CAM }\end{array}$ \\
\hline \multirow{8}{*}{ Bentonite } & \multirow{2}{*}{0} & Mean & $0.059^{\mathrm{Aa}}$ & $0.062^{\mathrm{Aa}}$ & $0.041^{\mathrm{Ab}}$ & $0.044^{\mathrm{Aa}}$ & $0.042^{\mathrm{Aa}}$ & $0.031^{\mathrm{Ab}}$ & $0.021^{\mathrm{Aa}}$ & $0.020^{\mathrm{Aa}}$ & $0.016^{\mathrm{Aa}}$ \\
\hline & & SD & 0.004 & 0.004 & 0.004 & 0.002 & 0.002 & 0.002 & 0.001 & 0.003 & 0.002 \\
\hline & \multirow{2}{*}{1} & Mean & $0.040^{\mathrm{Ba}}$ & $0.043^{\mathrm{Ba}}$ & $0.028^{\mathrm{Bb}}$ & $0.030^{\mathrm{Ba}}$ & $0.029^{\mathrm{Ba}}$ & $0.022^{\mathrm{Bb}}$ & $0.015^{\mathrm{Ba}}$ & $0.015^{\mathrm{Ba}}$ & $0.011^{\mathrm{Bb}}$ \\
\hline & & SD & 0.004 & 0.004 & 0.004 & 0.002 & 0.006 & 0.002 & 0.001 & 0.004 & 0.001 \\
\hline & \multirow{2}{*}{2} & Mean & $0.040^{\mathrm{Ba}}$ & $0.042^{\mathrm{Ba}}$ & $0.026^{\mathrm{Bb}}$ & $0.035^{\mathrm{Ba}}$ & $0.030^{\mathrm{Ba}}$ & $0.023^{\mathrm{Bb}}$ & $0.014^{\mathrm{Ba}}$ & $0.012^{\mathrm{Ba}}$ & $0.009^{\mathrm{Ba}}$ \\
\hline & & SD & 0.005 & 0.007 & 0.004 & 0.003 & 0.004 & 0.004 & 0.003 & 0.004 & 0.001 \\
\hline & \multirow{2}{*}{3} & Mean & $0.044^{\mathrm{Ba}}$ & $0.044^{\mathrm{Ba}}$ & $0.030^{\mathrm{Bb}}$ & $0.028^{\mathrm{Ca}}$ & $0.031^{\mathrm{Ba}}$ & $0.023^{\mathrm{Bb}}$ & $0.013^{\mathrm{Ba}}$ & $0.011^{\mathrm{Ba}}$ & $0.007^{\mathrm{Bb}}$ \\
\hline & & SD & 0.005 & 0.005 & 0.005 & 0.003 & 0.004 & 0.004 & 0.002 & 0.003 & 0.001 \\
\hline \multirow{8}{*}{ PAM } & \multirow{2}{*}{0} & Mean & $0.059^{\mathrm{Aa}}$ & $0.062^{\mathrm{Aa}}$ & $0.041^{\mathrm{Ab}}$ & $0.044^{\mathrm{Aa}}$ & $0.042^{\mathrm{Aa}}$ & $0.031^{\mathrm{Ab}}$ & $0.021^{\mathrm{Aa}}$ & $0.020^{\mathrm{Aa}}$ & $0.016^{\mathrm{Aa}}$ \\
\hline & & SD & 0.004 & 0.004 & 0.004 & 0.002 & 0.002 & 0.002 & 0.001 & 0.003 & 0.002 \\
\hline & \multirow{2}{*}{2} & Mean & $0.037^{\mathrm{Ba}}$ & $0.039^{\mathrm{Ba}}$ & $0.026^{\mathrm{Bb}}$ & $0.033^{\mathrm{Ba}}$ & $0.029^{\text {Ba }}$ & $0.021^{\mathrm{Bb}}$ & $0.013^{\mathrm{Ba}}$ & $0.011^{\mathrm{Ba}}$ & $0.009^{\mathrm{Ba}}$ \\
\hline & & SD & 0.006 & 0.004 & 0.005 & 0.003 & 0.004 & 0.004 & 0.004 & 0.004 & 0.002 \\
\hline & \multirow{2}{*}{4} & Mean & $0.034^{\mathrm{Ba}}$ & $0.036^{\mathrm{Ba}}$ & $0.021^{1 b}$ & $0.028^{\mathrm{Ca}}$ & $0.026^{\mathrm{Ba}}$ & $0.016^{\mathrm{Cb}}$ & $0.012^{\mathrm{Ba}}$ & $0.011^{\mathrm{Ba}}$ & $0.008^{\mathrm{Ba}}$ \\
\hline & & SD & 0.005 & 0.005 & 0.004 & 0.003 & 0.003 & 0.002 & 0.002 & 0.001 & 0.003 \\
\hline & \multirow{2}{*}{6} & Mean & $0.031^{\mathrm{Ba}}$ & $0.033^{\mathrm{Ba}}$ & $0.018^{\mathrm{Cb}}$ & $0.026^{\mathrm{Ca}}$ & $0.023^{\mathrm{Ba}}$ & $0.014^{\mathrm{Cb}}$ & $0.014^{\mathrm{Ba}}$ & $0.011^{\mathrm{Ba}}$ & $0.006^{\mathrm{Bb}}$ \\
\hline & & SD & 0.003 & 0.005 & 0.004 & 0.003 & 0.003 & 0.001 & 0.004 & 0.002 & 0.001 \\
\hline \multirow{8}{*}{ Molasses } & \multirow{2}{*}{0} & Mean & $0.059^{\mathrm{Aa}}$ & $0.062^{\text {Aa }}$ & $0.041^{\mathrm{Ab}}$ & $0.044^{\mathrm{Aa}}$ & $0.042^{\mathrm{Aa}}$ & $0.031^{\mathrm{Ab}}$ & $0.021^{\mathrm{Aa}}$ & $0.020^{\mathrm{Aa}}$ & $0.016^{\mathrm{Ab}}$ \\
\hline & & SD & 0.004 & 0.004 & 0.004 & 0.002 & 0.002 & 0.002 & 0.001 & 0.003 & 0.002 \\
\hline & \multirow{2}{*}{5} & Mean & $0.048^{\mathrm{Ba}}$ & $0.052^{\mathrm{Ba}}$ & $0.035^{\mathrm{Bb}}$ & $0.034^{\mathrm{Ba}}$ & $0.035^{\mathrm{Ba}}$ & $0.026^{\mathrm{Bb}}$ & $0.016^{\mathrm{Ba}}$ & $0.015^{\mathrm{Ba}}$ & $0.011^{\mathrm{Bb}}$ \\
\hline & & SD & 0.004 & 0.004 & 0.003 & 0.004 & 0.004 & 0.003 & 0.003 & 0.003 & 0.001 \\
\hline & \multirow{2}{*}{10} & Mean & $0.040^{\mathrm{Ca}}$ & $0.044^{\mathrm{Ca}}$ & $0.026^{\mathrm{Cb}}$ & $0.031^{\mathrm{Ba}}$ & $0.030^{\mathrm{Ca}}$ & $0.020^{\mathrm{Cb}}$ & $0.015^{\mathrm{Ba}}$ & $0.013^{\mathrm{Ba}}$ & $0.008^{\mathrm{Bb}}$ \\
\hline & & SD & 0.005 & 0.004 & 0.004 & 0.003 & 0.003 & 0.004 & 0.001 & 0.002 & 0.001 \\
\hline & \multirow{2}{*}{20} & Mean & $0.037^{\mathrm{Ca}}$ & $0.036^{\mathrm{Da}}$ & $0.021^{1 \mathrm{~b}}$ & $0.027^{\mathrm{Ba}}$ & $0.026^{\mathrm{Ca}}$ & $0.019^{\mathrm{Cb}}$ & $0.014^{\mathrm{Ba}}$ & $0.012^{\mathrm{Ba}}$ & $0.009^{\mathrm{Ba}}$ \\
\hline & & SD & 0.003 & 0.003 & 0.005 & 0.004 & 0.003 & 0.006 & 0.004 & 0.003 & 0.001 \\
\hline
\end{tabular}

Different little signs at each row and different capital signs at each column show significant difference at probability level of 95\%; SD - standard deviation 
the amount of deposited dust per unit leaf area of Parrotia persica CAM. was significantly less than that of Alnus subcordata L. and Carpinus betulus L. Significant difference was observed between the amount of deposited dust in Loveh and those of the other sites. There was more deposited dust on leaves of adjacent trees in treated road segments of Loveh forest than in those of Kouhmian and Shastkalateh (Fig.8). Liu et al. (2013) assessed the dust-retaining capability of Mangifera indica Linn. and Bauhinia blakeana in Guangzhou at different types of morphological traits of their leaves. Results showed that the leaf of Mangifera indica has deep grooves and high stomata density,
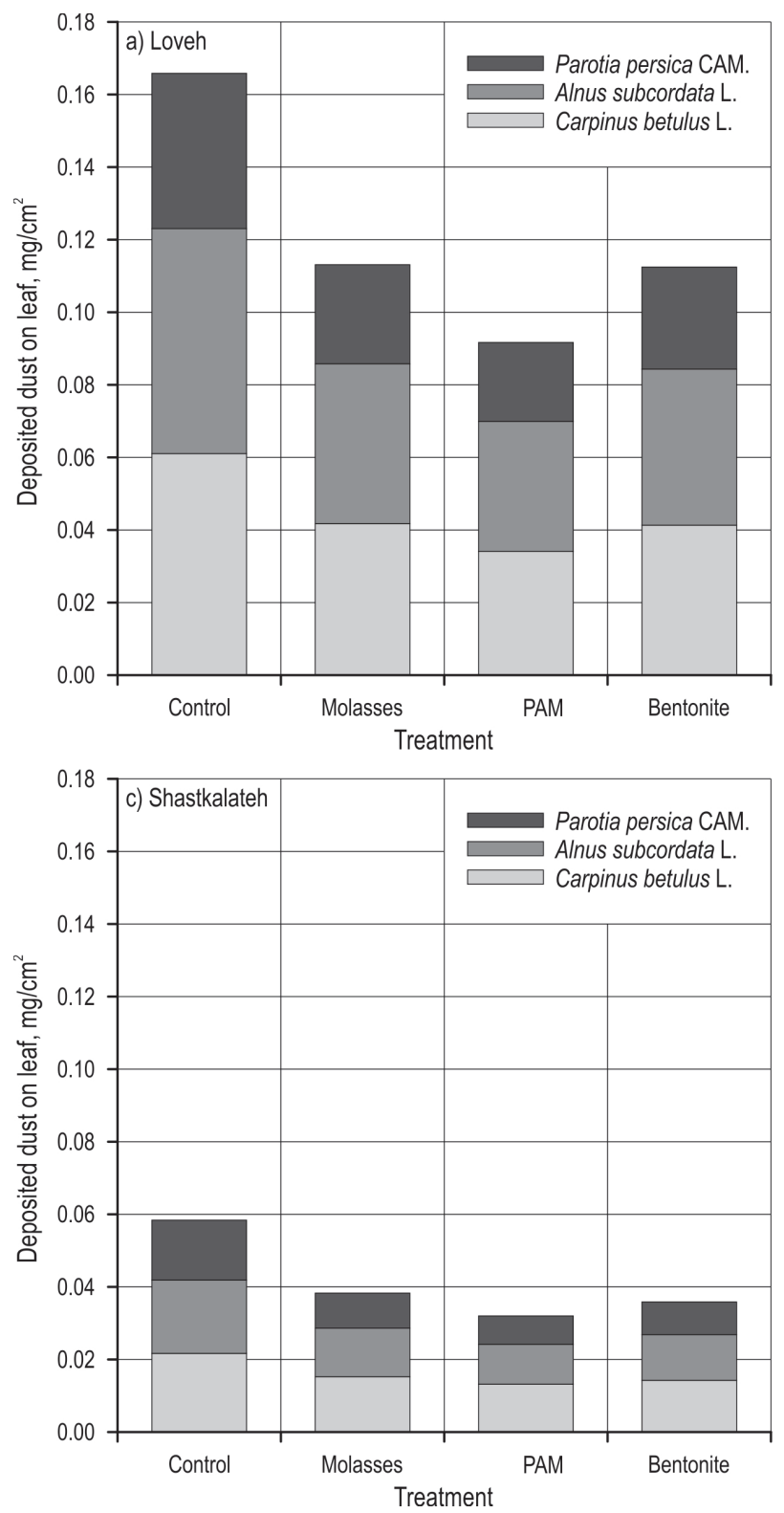

which are in favor of retaining dust, and thus, their dust-retained capability is stronger, while Bauhinia blakeana has the cells and epicuticular wax with its stomata arranging regularly, resulting in poor dust catching capability.

\subsection{Determination of Optimum Dosage with Consideration of Cost}

In Loveh forest, lowest emitted dust was recorded for PAM and molasses treated road segments with concentration of $6 \%$ and $20 \%$, respectively. The cost of implementation of PAM and molasses treatments with

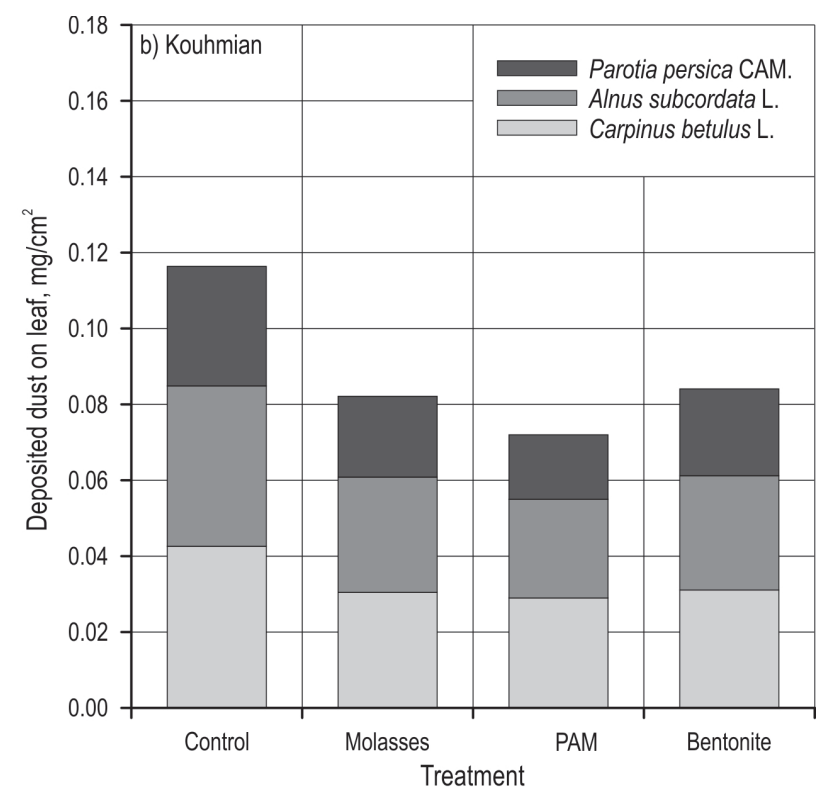

Fig. 8 Comparison of deposited dust on leaves of different species in treated road segments 
the above concentrations was $1400 \$ / \mathrm{km}$ and $1167 \$ / \mathrm{km}$, respecitely. Therefore, molasses with concentration of $20 \%$ was selected as optimum treatment for dust emission control in Loveh. In Kouhmian forest, lowest emitted dust was recorded for PAM and molasses treated road segments with concentration of $4 \%$ and $20 \%$, respectively. The cost of implementation of PAM and molasses treatments with the above concentrations was $933 \$ / \mathrm{km}$ and $1167 \$ / \mathrm{km}$, respectively. Therefore, PAM with concentration of $4 \%$ was selected as optimum treatment for dust emission control in Kouhmian. In Shastkalateh forest, PAM treated road segments with concentration of $2 \%$ and implementation cost of $467 \$ / \mathrm{km}$ was selected as optimum treatment (Table 6).

Table 6 Materials cost analysis of dust emission control in a 3.5-meter wide forest road

\begin{tabular}{|l|c|c|c|}
\hline Anti-dust agent & Concentration, $\%$ & $\mathrm{Kg} / \mathrm{km}$ & $\$ / \mathrm{km}$ \\
\hline \multirow{3}{*}{ Molasses } & 5 & 350 & 292 \\
\cline { 2 - 4 } & 10 & 700 & 583 \\
\cline { 2 - 4 } & 20 & 1400 & 1167 \\
\hline \multirow{3}{*}{ PAM } & 2 & 140 & 467 \\
\cline { 2 - 4 } & 4 & 280 & 933 \\
\hline \multirow{3}{*}{ Bentonite } & 6 & 420 & 1400 \\
\cline { 2 - 4 } & 1 & 400 & 33 \\
\cline { 2 - 4 } & 2 & 800 & 67 \\
\hline
\end{tabular}

\section{Conclusions}

Effectiveness of different anti-dust agents on forest road dust emissions was examined from emission data collected for 81 days by dustometer in three sites in Hyrcanian forests. Molasses was found to be an effective agent for controlling dust emissions from road surface with high levels of fines and unwashed materials (Fig. 9a). In forest roads with lower levels of fine particles in surfacing materials, PAM was the most efficient and cost effective method of dust emission reduction. Cohesive behavior of these agents can aggregate the fine particles of road surface (Fig. 9b). Moreover, the findings of the present study showed that dust retention varied between the three tree species studied; it also varied between concentrations and between study sites. Dust-retaining capability of Carpinus betulus L. and Alnus subcordata L. was better than that of Parrotia persica CAM. It is concluded that the amount of fine aggregates in surfacing materials, rainfall occurrence, and type of anti-dust agent and

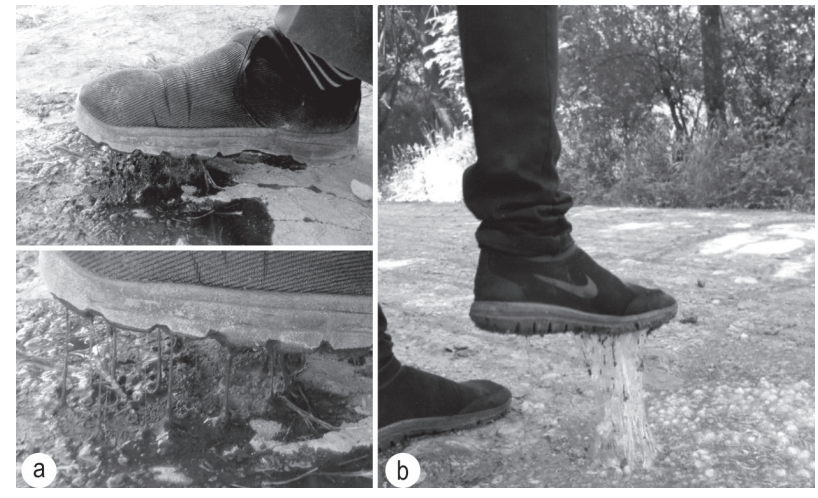

Fig. 9 Cohesive behavior of (a) sugar cane molasses and (b) PAM on road surface

dosage of anti-dust play an important role in the effectiveness and longevity of the treatment and amount of deposited dusts on leaves of adjacent trees. It is recommended that the effects of other environmentally friendly products, such as starch, vegetable oils and animal fats, on road dust emission be investigated in future studies. Further researches are also necessary to determine the exact longevity of anti-dust agents under different climate conditions.

\section{Acknowledgments}

We gratefully acknowledge Iran National Science Foundation (Vice-Presidency for Science and Technology) for the financial support of this work (Research plan No: 97007867). Special thanks are also given to Aiub Rezaee Motlaq, Aliakbar Pour Malekshah and Hassan Sasani for their assistance with fieldwork as well as anonymous reviewers for their valuable and constructive comments.

\section{References}

ASTM D422-63, 2007: Standard test method for particle-size analysis of soils (Withdrawn 2016), ASTM International, West Conshohocken, PA, 2007.

Addo, J.Q., Sanders, T.G., 1995: Effectiveness and environmental impact of road dust suppressants. MPC Report No. 95-28A. Fargo, ND: Mountain-Plains Consortium, 132 p.

Addo, J.Q., Sanders, T.G., Chenard, M., 2004: Road dust suppression: effect of maintenance stability, safety and the environment phases 1-3. Mountain-plains consortium (MPC), University Transportation Centers Program (UTCP), 73 p.

Bergeson, K.L., Brocka, S.G., 1996: Bentonite treatment for fugitive dust control. In: 1996 semi-sesquicentennial transportation conference proceedings. Ames, IA: Iowa Department of Transportation; Iowa State University, Center for Transportation Research and Education, 3 p. 
Bennett, F.L., 1994: Gravel roadway maintenance in cold regions. Report No. INE/TRC-94.05. Fairbanks, AK: University of Alaska, $68 \mathrm{p}$.

Bolander, P., Yamada, A., 1999: Dust palliative selection and application guide. Project Report 9977 1207-SDTDC. San Dimas, CA: U.S. Department of Agriculture, Forest Service, San Dimas Technology and Development Center, 20 p.

Brown, D.A., Elton, D.J., 1994: Guidelines for dust control on unsurfaced roads in Alabama. Final report, IR-94-02, Highway Research Center, Harbert Engineering Center, Auburn University, $20 \mathrm{p}$.

Ding, X., Xu, G., Liu, W.V., Yang, L., Albijanic, B., 2019: Effect of polymer stabilizers' viscosity on red sand structure strength and dust pollution resistance. Powder Technology 352: 117-125. https://doi.org/10.1016/j.powtec.2019.04.046

Edvardsson, K., 2010: Evaluation of dust suppressants for gravel roads: methods development and efficiency studies. PhD Thesis, Royal Institute of Technology Stockholm, Sweden, $70 \mathrm{p}$.

Edwards, P.J., Wood, F., Quinlivan, R.L., 2016: Effectiveness of best management practices that have application to forest roads: A literature synthesis. United States Department of Agriculture, General Technical Report NRS-163, 180 p.

Forman, R.T.T., Alexander, L.E., 1998: Roads and their major ecological effects. Annual Review of Ecology and Systematics 29(1): 207-231. https://doi.org/10.1146/annurev.ecolsys.29.1.207

Gulia, S., Goyal P., Goyal, S.K.,Kumar, R., 2019: Re-suspension of road dust: contribution, assessment and control through dust suppressants. International Journal of Environmental Science and Technology 16(3): 1717-1728. https:// doi.org/10.1007/s13762-018-2001-7

Gillies, J.A., Etyemezian, V., Kuhns, H., Nikolic, D., Gillette, D.A., 2005: Effect of vehicle characteristics on unpaved road dust emissions. Atmospheric Environment 39(13): 23412347. https://doi.org/10.1016/j.atmosenv.2004.05.064

Goma, J.M., Mwale, M.C., 2016: Zambia's experience on the use and performance of sulfonated petroleum products and other non-conventional soil stabilizers in road construction. Geo-China: 164-171.

Gotosa, J., Nyamadzawo, G., Mtetwa, T., Kanda, A., Dudu, V.P., 2015: Comparative road dust suppression capacity of molasses stillage and water on gravel road in Zimbabwe. Advances in Research 3(2): 198-208. https://doi.org/10.9734/ AIR/2015/13019

Jacobson, T., 1992: Low traffic roads stabilized with bitumen binders. Nordic Road and Transport Research 1: 22-23.

Jones, T.E., 1984: Dust emission from unpaved roads in Kenya. Laboratory report 1110, Transport and Road Research Laboratory, Crowthorne.

Jones, D., 1999: Holistic approach to research into dust and dust control on unsealed roads. Transportation Research Record 1652(2): 3-9. https://doi.org/10.3141/1652-35
Jones, D., 2000: Road dust - just a nuisance or a significant road management issue? In: Proceedings, South African transport conference. Pretoria, South Africa; Washington, DC: Transportation Research Board: $12 \mathrm{p}$.

Kirchner, H., Gall, J.A., 1991: Liquid calcium chloride for dust control and base stabilization of unpaved road systems. Transportation Research Record 1291: 173-178.

Kristian Aase, J., Bjorneberg, D.L., Sojka, R.E., 1998: Sprinkler irrigation runoff and erosion control with polyacrylamidelaboratory tests. Soil Science Society of America Journal 62(6): 77-85.https://doi.org/10.2136/sssaj1998.03615995006200060028x

Kuhns, H., Etyemezian, V., Landwehr, D., McDougall, C., Pitchford, M., Green, M., 2001: Testing re-entrained aerosol kinetic emissions from roads: a new approach to infer silt loadings on roadways. Atmospheric Environment 35(16): 2815-2825. https://doi.org/10.1016/S1352-2310(01)00079-6

Liu, L., Guan,D., Peart, M.R., Wang, G., Zhang, H., Li, Z., 2013: The dust retention capacities of urban vegetation, a case study of Guangzhou, South China. Environmental Science and Pollution Research 20(9): 6601-6610. https://doi. org/10.1007/s11356-013-1648-3

Lohnes, R.A., Coree, B.J., 2002: Determination and evaluation of alternate methods for managing and controlling highway related dust. Final Report TR 449. Prepared for: Iowa Department of Transportation, Iowa Highway Research Board. Ames, IA: Iowa State University, Department of Civil and Construction Engineering, 26 p.

Manoochehri, K., Shirvany, A., Attarod, P., Khodakarami, Y., 2016: Dust filtration ability of Fraxinus rotundifolia, Platanus orientalis, and Robinia pseudoacacia trees in Kermanshah, West of Iran. Iranian Journal of Forest 8(1): 1-10.

Manyuchi, M.M., Mbohwa, C., Muzenda, E., 2018: Value addition of coal fines and sawdust to briquettes using molasses as a binder. South African Journal of Chemical Engineering 26: 70-73. https://doi.org/10.1016/j.sajce.2018.09.004

Manafi, M.R., Manafi, P., Kehtari Karam, S., 2016: Prevent soil loss by copolymer based on polyacrylamide. Journal of Advanced Materials and Technologies 4(4): 6-11.

McLaughlin, R., Amoozegar A., Duckworth, O., Heitman, J., 2014: Optimizing soil-polyacrylamide Interactions for erosion control at construction sites. Water Resources Research Institute of the University of North Carolina. Report No. 441, 47 p.

Morgan, R.J., Schaefer, V.R., Sharma, R.S., 2005: Determination and evaluation of alternative methods for managing and controlling highway-related dust: Phase II- demonstration project. IHRB Project TR-506. Iowa Highway Research Board. Ames, IA: Iowa State University: Department of Civil, Construction, and Environmental Engineering, 107 p.

Monlux, S., Mitchell, M., 2007. Chloride stabilization of unpaved road aggregate surfacing. Transportation Research Record: Journal of the Transportation Research Board 1989(2): 50-58. https://doi.org/10.3141/1989-48 
Monlux, S., 2003: Stabilizing unpaved roads with calcium chloride. Transportation Research Record 1819(1): 52-56. https://doi.org/10.3141/1819b-07

Murray, H.H., 2000: Traditional and new applications for kaolin, smectite, and palygorskite: a general overview. Applied Clay Science 17(5-6): 207-221. https://doi.org/10.1016/ S0169-1317(00)00016-8

Omane, D., Liu, W.V., Pourrahimian, Y., 2018: Comparison of chemical suppressants under different atmospheric temperatures for the control of fugitive dust emission on mine hauls roads. Atmospheric Pollution Research 9(3): 561-568. https://doi.org/10.1016/j.apr.2017.12.005

Powers, R.L., 2007: Low-volume state highways in Arizona. Innovative Approaches. Journal of the Transportation Research Board 1989(1): 272-280. https://doi.org/10.3141/1989-32

Pusch, R., 2015: Bentonite clay: Environmental properties and applications. CRC press, $360 \mathrm{p}$.
Sadeghi, S.H.R., Raisi, M.B., Hazbavi, Z., 2016: Effects of polyacrylamide in controlling of splash erosion from a soil induced freeze-thaw cycle. Journal of Water and Soil 29(6): 1601-1611. https://doi.org/10.22067/jsw.v29i6.36782

Sanders, T.G., Addo, J.Q., Ariniello, A., Heiden, W.F., 1997: Relative effectiveness of road dust suppressants. Journal of Transportation Engineering 123(5): 393-397.

Sanders, T.G., Addo, J.Q., 2000: Experimental road dust measurement device. Journal of Transportation Engineering, ASCE126(6): 530-538. https://doi.org/10.1061/(ASCE)0733947X(2000)126:6(530)

Shirsavkar, S.S., Koranne, S.S., 2010: Innovation in road construction using natural polymer. EJGE 15: 1614-1624.

Thompson, R.J., Visser, A.T., 2007: Selection, performance and economic evaluation of dust palliatives on surface mine haul roads. Journal of The Southern African Institute of Mining and Metallurgy 107(7): 435-450.

(C) 2021 by the authors. Submitted for possible open access publication under the terms and conditions of the Creative Commons Attribution (CC BY) license (http://creativecommons.org/licenses/by/4.0/). 
Authors' address:

Assist. prof. Aidin Parsakhoo, PhD * e-mail: Parsakhoo@gau.ac.ir Gorgan University of Agricultural Sciences and Natural Resources

Faculty of Forest Science

Basij Square

Gorgan, 49189-43464

IRAN

Prof. Seyed Ataollah Hosseini, PhD

e-mail: at.hosseini@ut.ac.ir

University of Tehran

Faculty of Natural Resources

Daneshkadeh Ave

Karaj, 77871-31587

IRAN

Prof. Majid Lotfalian, $\mathrm{PhD}$

e-mail: mlotfalian@sanru.ac.ir

Sari Agricultural Sciences

and Natural Resources University

Faculty of Natural Resources

9 km Darya Road

Sari, Mazandaran

IRAN

Assist. prof. Jahangir Mohammadi, $\mathrm{PhD}$

e-mail: Mohamdi.jahangir@gmail.com

Gorgan University of Agricultural Sciences and Natural Resources

Faculty of Forest Science

Basij Square

Gorgan, 49189-43464

IRAN

Assist. prof. Meysam Salarijazi, PhD

e-mail: meysam.salarijazi@gau.ac.ir

Gorgan University of Agricultural Sciences

and Natural Resources

Faculty of Water and Soil Engineering

Basij Square

Gorgan, 49189-43464

IRAN

Received: August 24, 2019

* Corresponding author 